\title{
Political Language Variation: Stylistic Based Study
}

\section{Ida Bagus Putrayasa}

Universitas Pendidikan Ganesha, Singaraja, Indonesia

\begin{abstract}
This study aimed at finding out the figures of speech used by the government in the political language variation and the purposes to which they serve. Based on the data analysis, it was found that there are sixteen types of figures of speech contained in the political language variation, for example, euphemism, repetition, parallelism, personification, parable, anticlimax, sarcasm, trope, hyperbole, pleonasm, climax, antithesis, synecdoche, anaphor, allusion, and metonymy. The purposes of their uses are to vary sentences, to show respect, to express something reasonably, and to give an emphasis or stress meanings. The suggestion made concerning the uses of the figures of speech in political language variation is for the authority (government) to use words or phrases that are simple to make it easy for the people to understand.
\end{abstract}

Keywords--- morphology, personification, political language variation, stylistics, syntax.

\section{Introduction}

Language is essentially a system of sound symbols that is arbitrary (Sibarani, 1992; Aronoff \& Rees-Miller, 2003). That is, there is no mandatory relationship between the symbol as the thing that marks the tangible word and the marked object or concept, that is, the reference of the word. The arbitrage of language symbols causes people to neglect research on meaning somewhat when compared to research in the fields of morphology and syntax. The meaning as an object of semantic study is very unclear in its structure. It is different from morphology and syntax which have a clear structure so that it is easy to analyze. However, now people are starting to realize that language activity is an activity of expressing language symbols to convey the meanings that exist in these symbols to the interlocutor (in oral communication) or the reader (in written communication). So, knowledge of the relationship between a symbol or language unit, and its meaning is very necessary for communicating with that language (Aronoff \& Rees-Miller, 2003).

Linguistics and Culture Review @ 2021.

Corresponding author: Putrayasa, I.B.; Email: ibputra@gmail.com

Manuscript submitted: 9 July 2020, Manuscript revised: 27 Sept 2020, Accepted for publication: 12 Jan 2021 
Language has a very important role in social life. With language, a person can express his thoughts in a unique way that shows his soul and personality. It is also with language that a person gets certain effects, both practical effects to attract attention in everyday conversation and aesthetic effects in literary works, and with language one can achieve his goals in all fields. No exception in the political field. A person who deals with political issues will use political language. The political language that is commonly used is the language that can be used to dodge or run away when an attack occurs. In the arena and political struggles, political people, especially the government (officials) must not admit defeat. In other words, political language is the language of victory, a language that ensures that its users will never be cornered. To avoid accusations of raising tariffs, the government uses the term 'tariff adjustment'. To avoid being accused of committing an offense, it is said to be a 'procedural error' (Kawulusan, 1998; Fatah, 1999).

Euphemism as a form of language style also colors the use of language which automatically reflects the socio-cultural conditions of society, namely the uncertainty of facing facts; which in the end the substance of the problem becomes obscured by language symbols. Apart from the examples mentioned above, we can also see the substance of the vocabulary of corruption and hunger which became vague after discussing politics as the commercialization of positions and food insecurity. The responsible party is also safe behind this euphemism. Meanwhile, the community becomes less sensitive to the substance of the problem. In other words, society is less critical. Euphemisms contain the danger of blunting a sense of social solidarity and social ignorance (Creswell, 1998; Denscombe, 1998; Alwasilah, 1997).

The various political languages put forward by the government are socialized to the public through mass media. By using the mass media (newspapers) it is hoped that the information will expand, both in the number of people and the area that can be reached. In socializing political language with a distinctive language style through the mass media, the role of journalists is indispensable in bridging the information that the government says to convey to the wider community. In this case, journalists do not have to completely copy what is conveyed by the government, but it should be filtered first using simpler words without changing the intended meaning. Sumarno (1998) states that communication media can help multiply communication messages conveyed to the public, both regionally, nationally, and internationally.

The variety of political language spoken by the government is packaged in confusing vocabulary, uses a distinctive language style, and contains figurative, not denotative meanings, making it difficult for the public to understand. Also, there are many problems in the variety of political language that is camouflage, meaning that something is pronounced differently from its true (ironic) purpose. For example, people who protest against existing inequalities are said by the government to be anti-establishment. The government says that people who hold demonstrations to demand their rights are counterproductive, and so on.

When viewed in-depth, the variety of political languages used by the government and published in the mass media (newspapers) today seems to emphasize the 
political aspect rather than provide a clear understanding of society. That is, political language often contains two aspects of meaning and what is meant is not the real meaning. This will affect people's perceptions, both positive and negative. Also, people become confused because they lose direction and guidance, which can lead to a crisis of confidence.

Stylistics are (1) the study of the language used in literary works; interdisciplinary science between linguistics and literature; (2) the application of linguistics to language style research. Stylistics is knowledge of the word soul. The word soul is a word used in literary works that contain the feelings of the author. It is argued that the stylistic task is to reveal the impression of using wording in sentences to the reader which plays an important role in literary creation besides the accuracy of word choice (Pradopo, 2004). From this understanding, it can be concluded that stylistics is the science of language style. In the Big Indonesian Dictionary, it is stated that stylistics is the science of the use of language and language styles in literary works. Studies of language styles can include styles of spoken language, but stylistics tends to study written language including literary works (Richards \& Renandya, 2002).

However, stylistics is not only the study of language style in literature but also the study of styles in the language in general although there is special attention to the most basic and most complex literary language. It was stated by Pradopo (2004) that stylistics is a part of linguistics that focuses on variations in language use. Stylistics means studies that suggest a form of science or at least a methodical study.

Pradopo (2004) stated that language style is a composition of speech that occurs because of feelings in the author's heart, which intentionally or not, creates certain feelings in the reader's heart. This is also evident in the definition of Keraf which says that the language style is a way of expressing thoughts through language in a distinctive way that shows the soul and personality of the writer or language speaker.

The language style is the use of language specifically to get certain effects, both practical effects to attract attention in everyday conversation and aesthetic effects in literary works. Likewise, Hartoko (1986) stated that the language style is a typical way used by someone to express oneself (personal style). Style of language is how the speaker of the language said about whatever he said (Abrams, 1983). Meanwhile, Kridalaksana (1993) stated more specifically that language style is the use of certain language variations to obtain certain effects, and more broadly, the language style is the overall language characteristics of a group of writers or language users.

Judging from the meaning of the word, the word style means the way to appear or how to show oneself. Enkvist (2016) suggested six meanings of the word style as follows. Style is (a) a wrap that covers the core of a pre-existing thought or statement, (b) a choice between various possible statements, (c) a set of personal characteristics, (d) a deviation from a norm or rule, (e) a set of collective characteristics, and (f) the relationship between language units that are more than one sentence. Because language here functions as the medium or the 
intermediary, then the whole sense of language style is a way of presenting oneself in language. Therefore, from the language style, a person's situation will be seen. With a good language style, someone's assessment of it will be good.

Because language style is closely related to language, naturally all linguistic elements will be linked in it. The linguistic elements include the choice of words, phrases, clauses, and sentences. Apart from that, the style of language also concerns the personal color of the speaker. That is why the language style is also individual. The use of language style is essentially a language activity as well. Some of these language activities are good and some are not good. Likewise the use of language style. A language style is said to be good if it contains three bases, namely: honesty, courtesy, and attractiveness.

Honesty means conveying ideas not using complicated language, using great words just to cover up shortcomings or to hide certain purposes. So you have to go straight to something he wants to convey. Manners here mean not using polite language full of pleasantries, or sweet words, but respect that is manifested through clarity and brevity. So, readers don't have to rack their brains to find out what the speaker is saying. Meanwhile, what is meant by interesting is a language style that can be measured through the components: variety, healthy humor, good sense, lively, and full of imagination.

Talks about language styles are very diverse. This is due to the different basic classification. If it is based on the speakers, of course, there are many and impossible. If it is based on linguistic elements, it will result in overlapping. Since the purpose of style is to attract attention, it would be better if the basis on which it is used is a means of achieving that goal. There are several ways to attract attention, namely: by repeating, comparing, contrasting, or linking both the content and the words. That is why various language styles can be grouped into (1) comparative language styles; (2) conflicting language style; (3) linking language style, and (4) repetition language style (Müller, 2008; Janssens et al., 2004; Valentine \& Skelton, 2007).

Based on the statements that have been stated above, the researcher can formulate research problems as follows. 1) What language styles does the government use in the various political languages in the Bali Post newspaper? 2) What is the purpose of the use of language styles in various political languages by the government in the Bali Post newspaper? Following the problem formulation that has been described above, the objectives of this study are 1) To obtain an overview of the style of language used by the government in various political languages in the Bali Post newspaper; and 2) To obtain an overview of the purpose of the use of language styles in various political languages by the government in the voice of the Bali Post newspaper.

\section{Research methods}

The research design used in this study is a qualitative research design, which is an effort to plan and determine all the possibilities and equipment needed in qualitative research (Lincoln \& Guba, 1985; Fetzer \& Weizman, 2006; Halmari, 2011; Sriwimon \& Zilli, 2017). 


\section{Subjects and Objects}

The subject of this research is an article taken from the Bali Post newspaper from April to June 2006, which contains the fields of economy, law, and politics (government). Research data was taken from the Bali Post newspaper that month because it contained news about the political situation that was not conducive (especially those related to the uncovering of corruption cases involving many people). Also, the state of the country's economy is uncertain. Meanwhile, the object of this research is the language style contained in the variety of political languages spoken by the government regarding government policies on the life of society, nation, and state (Turner, 2004; McOuat, 1996; Zupnik, 1994; Pan \& Block, 2011).

\section{Data Collection Techniques}

Data collection activities were carried out by recording documents (Denscombe, 1998). In this case, the Bali Post newspaper is the source of data. The methods taken are: 1) read newspapers used as data sources carefully, 2) mark sentences that contain language styles in a variety of political languages with the highlighter, 3) make a card measuring $8 \mathrm{~cm} \times 15 \mathrm{~cm}$, 4) note down sentences that contain language styles in various languages political, 5) data taken from the newspaper is coded. For example, BP4: 1, hl means letter Bali Post news, month 4 (April), the 1st, page 1. For more details can be seen as an example below.

(2) The government adjusts the fuel price rate starting in March 2019.

(BP4:1,hl)

The card above shows that the data is data 2 from the Bali Post newspaper, April, the 1 st, page 1 .

\section{Data Analysis Techniques}

The collected qualitative research data were analyzed inductively (Lincoln \& Guba, 1985). This means that specific things that are found during the study are grouped, then abstraction is made (Bogdan \& Biklen, 1990). Also, the collected data were not used to prove or reject the hypotheses made before the study began but were used to facilitate data description.

\section{Research Results}

Based on research conducted in the Bali Post Newspaper during the period April June 2019, research data was obtained as much as fifty-seven types of political language, which are scattered in the fields of economy, law, and politics (government). In the research data, there are sixteen types of language styles. The fifty-seven research data that have been identified, both studied in terms of the variety of a political language as well as in terms of language style can be tabled as below. 
Table 1. Frequency of Appearance of Language Styles in Various Political Languages

\begin{tabular}{|c|l|l|l|l|l|}
\hline No. & $\begin{array}{l}\text { Variety of } \\
\text { Languages Political } \\
\text { Language style }\end{array}$ & $\begin{array}{l}\text { Economy } \\
\text { Sector }\end{array}$ & $\begin{array}{l}\text { Field of } \\
\text { Law }\end{array}$ & $\begin{array}{l}\text { Politics } \\
\text { (Government) }\end{array}$ & Total \\
\hline 1 & Euphemism & 3 & 3 & 5 & 11 \\
\hline 2 & Repetition & 1 & 1 & 4 & 6 \\
\hline 3 & Parallelism & 1 & 2 & 3 & 6 \\
\hline 4 & Personification & & 1 & 4 & 5 \\
\hline 5 & Parable & & 1 & 4 & 5 \\
\hline 6 & Anticlimax & 1 & 1 & 2 & 4 \\
\hline 7 & Sarcasm & & 3 & 1 & 4 \\
\hline 8 & Tropen & 2 & 1 & 3 \\
\hline 9 & Hyperbole & 1 & 1 & 1 & 3 \\
\hline 10 & Redundancy & & 2 & 1 & 2 \\
\hline 11 & Climax & & & & 2 \\
\hline 12 & Antithesis & & & 2 & 2 \\
\hline 13 & Synecdoche & & 1 & 1 & 1 \\
\hline 14 & Anaphora & & & 1 & 1 \\
\hline 15 & Allusion & & 19 & 31 & 1 \\
\hline 16 & Metonymy & & & 57 \\
\hline & Total & 7 & & 1 & \\
\hline
\end{tabular}

\section{Discussion}

There are sixteen types of language styles used by the government in various political languages in the Bali Post newspaper. The sixteen types of language styles are: euphemistic language styles $(11$ pieces $=19.2 \%$ of the 57 sentences of various political language styles obtained). Followed by repetition and parallelism (6 $=10.5 \%$ each), personification and parable $(5=8.7 \%$ each $)$, anticlimax and sarcasm (respectively). $4=7.0 \%)$, tropen and hyperbole $(3=5.2 \%)$, pleonasm, climax, and antithesis $(2=3.5 \%$ each), and synecdoche, anaphora, allusion, and metonymy $(1=1.7 \%$ each $)$.

Based on these findings, it can be said that the language style used in various political languages by the government in the print media (Bali Post) tends to lead to the refinement of language use. This is following the findings of research conducted by Putrayasa $(2015 ; 2017 a, b)$. In his research on the variety of political language studied in terms of these semantics, most of the words or phrases used by the government are words that mean class and tend to refine the language (euphemisms). To avoid accusations of raising tariffs, the government uses the term 'tariff adjustment'. To avoid being accused of committing an offense, it is said to be a 'procedural error' (Kawulusan, 1998; Fatah, 1999).

Euphemism as a form of language style embodies the use of language which automatically reflects the socio-cultural conditions of society, namely the uncertainty of facing facts; which in the end the substance of the problem becomes obscured by language symbols. Apart from the examples mentioned 
above, we can also see the substance of the vocabulary of corruption and hunger which became vague after discussing politics as the commercialization of positions and food insecurity. The responsible party is also safe behind this euphemism. Meanwhile, the community becomes less sensitive to the substance of the problem. In other words, society is less critical. Euphemisms contain the danger of blunting a sense of social solidarity and social ignorance (Alwasilah, 1997).

Also, the language style used by the government in a variety of political languages implies: repeating several times something that is considered important and aligning several things for the effective delivery of messages; insertion of inanimate objects and the comparison between two things that have different properties; delivery of messages from less important to important things or vice versa, and even to deliver messages roughly; the superficial and intended alignment of meanings; delivering messages with redundant and opposite meanings; delivery of messages by calling the whole for part or vice versa, delivering messages by repeating several times the things that are considered important, indicating something indirectly to something, and using the name of an item to replace the item.

\section{Conclusion}

The results of the analysis and discussion show that the language style used by the government in a variety of political languages is the euphemistic language style $(11$ pieces $=19.2 \%$ of the 57 sentences of various political languages obtained). Followed by repetition and parallelism ( $6=10.5 \%$ each), personification and parable $(5=8.7 \%$ each), anticlimax and sarcasm (respectively). $4=7.0 \%$ ), tropen and hyperbole $(3=5.2 \%)$, pleonasm, climax, and antithesis $(2=3.5 \%$ each), and synecdoche, anaphora, allusion, and metonymy ( $1=1.7 \%$ each).

The purpose of the use of language style by the government in various political languages in the print media (Bali Post) is to vary sentences, to respect or appreciate, to smooth, and to emphasize or reinforce intent. Based on the description above, several suggestions can be put forward as follows. In presenting political policies to the public, the government should use simple words or phrases or language that is easily digested by the public. This is very important and useful so that programs or policies made can be understood and run smoothly without different responses from the community. On the other hand, journalists as media crews or caregivers of print media should be able to filter out the languages to be published so that what is meant is not distorted. Newspaper language should be short, simple, and clear so that it is easily understood by readers of various intellectual levels. Therefore, journalists are required to play an active role in packaging news or information to be published. To avoid irregularities in creating communicative language, the contribution of language experts is expected to provide constructive input or criticism of the use of language in newspapers, especially the variety of political languages spoken by the authorities or officials or the government. 


\section{Acknowledgments}

I am grateful to two anonymous reviewers for their valuable comments on the earlier version of this paper.

\section{References}

Abrams, P. (1983). The theory of limiting similarity. Annual review of ecology and systematics, 14(1), 359-376.

Alwasilah, A. C. (1997). Politik bahasa dan pendidikan. Remaja Rosdakarya.

Aronoff, M., \& Rees-Miller, J. (Eds.). (2003). Handbook of Linguistics, The. Blackwell Handbooks in Linguistics. Wiley.

Bogdan, R. C., \& Biklen, S. K. (1990). Penelitian Kualitatif untuk Pendidikan. Jakarta: Pusat Antar Universitas.

Creswell, J. W. (1998). W. 1994. Research Design Qualitative \& Quantitative Approaches.

Denscombe, M. (1998). The good guide for small scale social research projects.

Enkvist, N. E. (2016). Linguistic stylistics (Vol. 5). Walter de Gruyter GmbH \& Co KG.

Fatah, E. S. (1999). Otoritarianisme dan distorsi bahasa. In Makalah disajikan pada Seminar Politik Bahasa, di Cisarua, Bogor, tanggal (pp. 9-1).

Fetzer, A., \& Weizman, E. (2006). Political discourse as mediated and public discourse. Journal of Pragmatics, 38(2), 143-153. https:/ / doi.org/10.1016/j.pragma.2005.06.014

Halmari, H. (2011). Political correctness, euphemism, and language change: The case of 'people first'. Journal of Pragmatics, 43(3), 828-840. https:/ /doi.org/10.1016/j.pragma.2010.09.016

Hartoko, D. (1986). Pemandu di dunia sastra. Kanisius.

Janssens, M., Lambert, J., \& Steyaert, C. (2004). Developing language strategies for international companies: The contribution of translation studies. Journal of World Business, 39(4), 414-430. https://doi.org/10.1016/j.jwb.2004.08.006

Kawulusan, H. E. (1998). Bahasa politik dalam bahasa Indonesia. Makalah disajikan dalam Kongres Bahasa Indonesia VII. Jakarta: Depdikbud.

Kridalaksana, H. (1993). Linguistic Dictionary. Jakarta: PT Gramedia Pustaka Utama.

Lincoln, Y. S., \& Inquiry, E. G. N. (1985). Sage Publication Inc. Newbury Park, London, New Delhi.

McOuat, G. R. (1996). Species, rules and meaning: the politics of language and the ends of definitions in 19th century natural history. Studies in History and Philosophy of Science Part A, 27(4), 473-519. https://doi.org/10.1016/00393681(95)00060-7

Müller, M. (2008). Reconsidering the concept of discourse for the field of critical geopolitics: Towards discourse as language and practice. Political geography, 27(3), 322-338. https://doi.org/10.1016/j.polgeo.2007.12.003

Pan, L., \& Block, D. (2011). English as a "global language" in China: An investigation into learners' and teachers' language beliefs. System, 39(3), 391402. https://doi.org/10.1016/j.system.2011.07.011

Pradopo, R. D. (2004). Stilistika. Makalahdalam.

Putrayasa, I. B. (2017a). The semantic study of languages politics. International journal of linguistics, literature and culture, 3(2), 7-13. 
Putrayasa, I.B. (2015). Polisemi dalam Bahasa Indonesia. Proceeding International Conference Linguistic Scientific Meeting. Bandung, 28 May 2015.

Putrayasa, I.B. (2017b). Analysis of Students' Misconceptions: Understanding: the Meaning of Denotation and Connotation. The Proceeding of the 2nd Asian Education Symposium (AES 2017), pp. 473-477.

Richards, J. C., \& Renandya, W. A. (Eds.). (2002). Methodology in language teaching: An anthology of current practice. Cambridge university press.

Sibarani, R. (1992). Hakikat Bahasa. Penerbit PT. Citra Aditya Bakti.

Sriwimon, L., \& Zilli, P. J. (2017). Applying Critical Discourse Analysis as a conceptual framework for investigating gender stereotypes in political media discourse. Kasetsart Journal of Social Sciences, 38(2), 136-142. https://doi.org/10.1016/j.kjss.2016.04.004

Sumarno, A. P. (1989). Dimensi-dimensi komunikasi Politik. Bandung: Citra Aditya Bakti.

Turner, J. (2004). Language as academic purpose. Journal of English for Academic Purposes, 3(2), 95-109. https://doi.org/10.1016/S1475-1585(03)00054-7

Valentine, G., \& Skelton, T. (2007). The right to be heard: Citizenship and language. Political Geography, 26(2),

121-140. https://doi.org/10.1016/j.polgeo.2006.09.003

Zupnik, Y. J. (1994). A pragmatic analysis of the use of person deixis in political discourse. Journal of pragmatics, 21(4), 339-383. https://doi.org/10.1016/0378-2166(94)90010-8 